RFP-2722 


\section{DISCLAIMER}

This report was prepared as an account of work sponsored by an agency of the United States Government. Neither the United States Government nor any agency Thereof, nor any of their employees, makes any warranty, express or implied, or assumes any legal liability or responsibility for the accuracy, completeness, or usefulness of any information, apparatus, product, or process disclosed, or represents that its use would not infringe privately owned rights. Reference herein to any specific commercial product, process, or service by trade name, trademark, manufacturer, or otherwise does not necessarily constitute or imply its endorsement, recommendation, or favoring by the United States Government or any agency thereof. The views and opinions of authors expressed herein do not necessarily state or reflect those of the United States Government or any agency thereof. 


\section{DISCLAIMER}

Portions of this document may be illegible in electronic image products. Images are produced from the best available original document. 


\section{LEGAL NOTICE}

This report was prepared as an account of work sponsored by the United States Government. Neither the United States nor the Department of Energy, nor any of their employees, nor any of their contractors, subcontractors, or their employees, makes any warranty, expressed or implied, or assumes any legal liability or responsibility for the accuracy, completenesss or usefulness of any information, apparatus, product or process disclosed, or represents that its use would not infringe privately owned rights.

Printed in the United States of America

Available from the

National Technical Information Service

U. S. Department of Commerce

Springfield, Virginia 22161

Price: Printed Copy $\$ 4.50$ Microfiche $\$ 3.00$

Price Is Subject to Change Without Notice 
Printed

May 31, 1978
RFP-2722

UC-38 ENGINEERING AND EQUIPMENT

TID4500-R66

EVALUATION OF PLASMA ARC

\section{WELDING CAPABILITIES AND APPLICATIONS}

G. Scott Mills

Fabrication Technology R\&D

JOINING R\&D

\section{SUBJECT DESCRIPTORS}

Plasma Arc Welding Heat Affected Zone Stainless Steel 21-6-9
ROCKWELL INTERNATIONAL ATOMICS INTERNATIONAL DIVISION ROCKY FLATS PLANT P. O. BOX 484 GOLDEN, COLORADO 80401

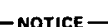

This repon was prepared as an account of wo sponsored by the United States Govemment. Neither the United States nor the United States Department of Energy, nor any of their employees, nor any of their contractors, subcontractors, or their employees, makes any warranty, express or implied, or assumes any legal liability or responsibility for the accuracy, completeness or usefulness of any information, apparatus, product or

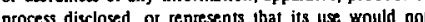
infringe privately owned nets.

Prepared under Contract EY.76:C.04.3533 for the Albuquerque Operations Office U. 8. Departmont of Enorgy 


$$
-
$$


CONTENT S

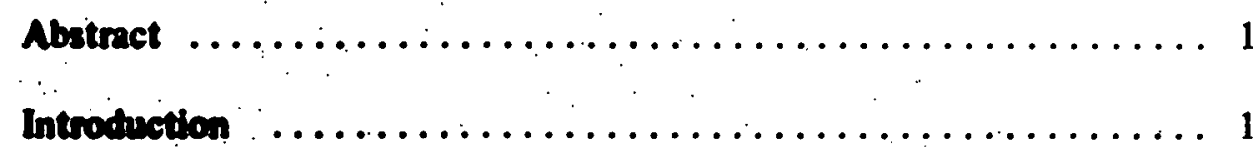

Equipwent and Process Description .................

Exposimental Evaluations $\ldots \ldots \ldots \ldots \ldots \ldots \ldots \ldots \ldots \ldots$

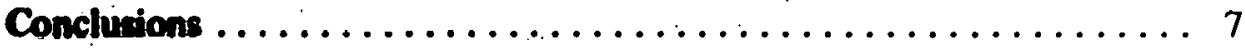


RF̈P-2722 
RFP-2722

\title{
EVALUATION OF PLASMA ARC \\ WELDING CAPABILITIES AND APPLICATIONS
}

\author{
G. Scott Mills
}

\begin{abstract}
Unique capabilities of plasma arc welding in the keyhole mode are described, and the potential applicability of these capabilities to Rocky Flats production needs are evaluated. For the areas of potential benefits studied, the benefits of this welding technique either did not materialize or the complication of implementing the process in production was not warranted by the demonstrated benefits.
\end{abstract}

\section{INTRODUCTION}

Plasma arc equipment has been available for a number of years at the Rocky Flats Plant, but a cursory investigation indicated that it was not being used for welding. Experimental welds had been made when suitable equipment was first purchased, but the results were not encouraging. Checking with the manufacturer indicated that within industry there were only a few users of his equipment. When contacted in June 1976, the British Welding Institute emphasized the difficulties in controlling this process in the keyhole mode. Institute personnel also mentioned that pulsed plasma arc welding is a more promising development exercise.

Because Rocky Flats' welding needs are often unique, a more thorough evaluation of the process and its potential for meeting specific needs was undertaken. Initial testing showed that in the keyhole mode, three areas of potential benefit existed:

1. The process was less sensitive than gas tungsten arc (GTA) welding to aluminum content in 21-6-9 stainless steel.

2. Welds in narrow grooves could be made without spatter on the underside.

3. Full penetration welds could be made at much lower currents. (A possible inplication could be a smaller heat affected zone.) This report presents the results of further studies of these benefits and their applicability to present and anticipated needs at Rocky Flats.

\section{EQUIPMENT AND PROCESS DESCRIPTION}

The equipment and the basics of its operation may be understood from the schematic in Figure 1. The orifice gas flow is set and a pilot arc struck between the electrode and orifice. Welding can then proceed by turning on the shielding gas and closing the contactor. Shown in Figure 2 is the range of parameters typically used with the two orifices that are suitable for keyhole welding plus the conditions that those parameters and orifices will handle. A key item that is not included here is a means of slope-in and slope-out. During this study, the equipment was modified to provide for sloping Orifice Gas flow and Transferred Arc current in a synchronized manner. At the same time, the best procedure for each weld type was determined. The shielding gas used in the present studies was either $100 \%$ argon or $5 \%$ hydrogen in argon.

The keyhole welding mode depends on the concentrated pressure that is exerted on the weld pool surface by the plasma jet from the orifice. It also depends on surface tension of the liquid metal. A clear hole is forced through the workpiece and as the arc moves on, surface tension closes the hole and forms a weld joint.

Transverse and longitudinal sections of a typical keyhole are shown schematically in Figure 3. Energy from the arc is deposited throughout the thickness of the work piece, which is the primary reason welds can be made in this mode with substantially less current than in gas tungsten arc (GTA) welding. Plasma arc equipment used in the melt-in 
RFP-2722

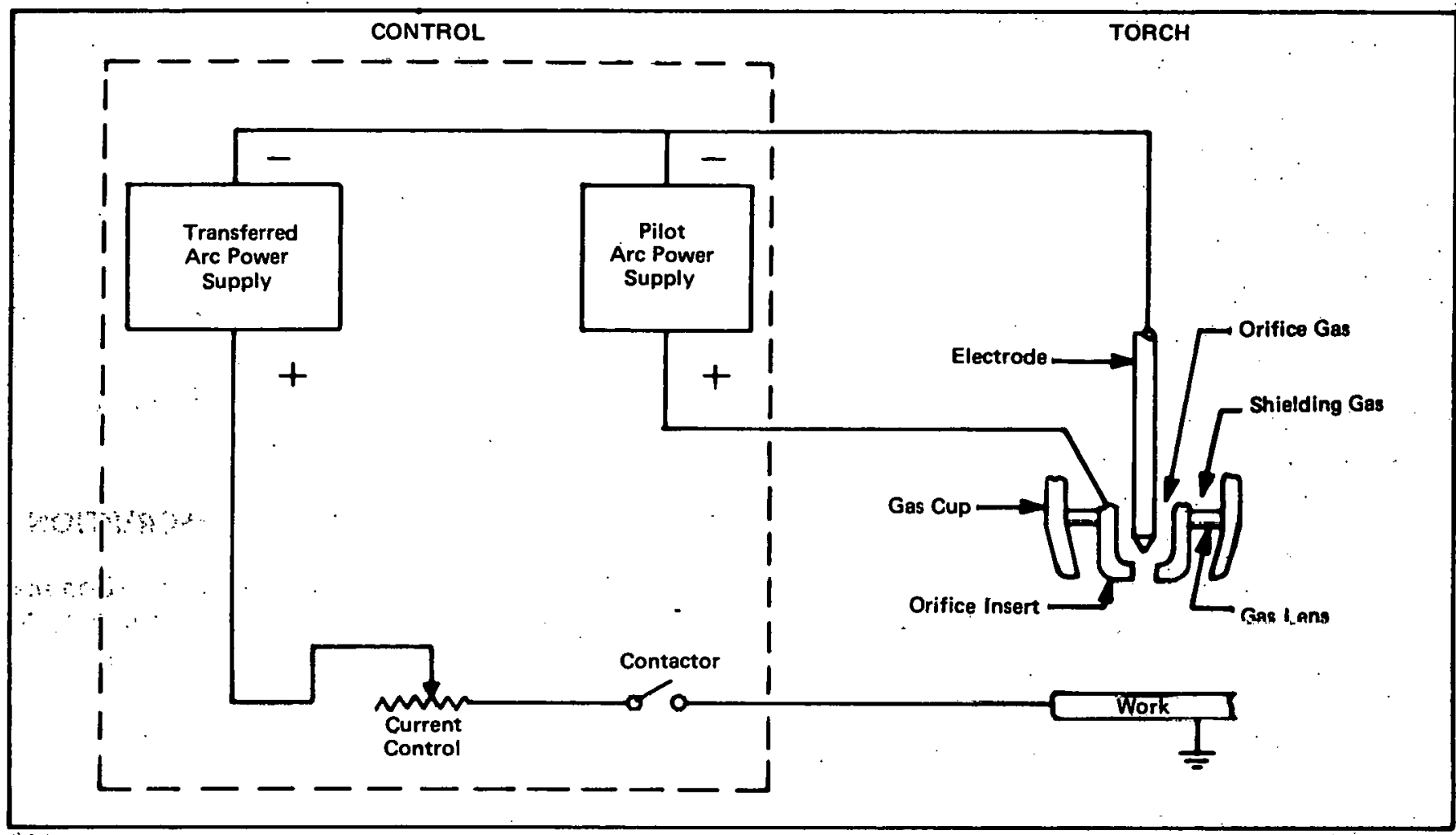

Figure 1. Plasma Arc Welding Power Supplies and Torch

Figure 2. Parameters and Orifices, as Suggested by the Equipment Manutantureir, fnr Reyhole Mude Bull Welds in Various Thicknesses of Stainless Steel and Carbon Steel

\begin{tabular}{|c|c|c|c|c|c|c|}
\hline $\begin{array}{l}\text { Workpiece } \\
\text { Thickness } \\
\text { (in.) }\end{array}$ & $\begin{array}{l}\text { Orifice } \\
\text { Dia. } \\
\text { (in.) }\end{array}$ & $\begin{array}{l}\text { Electrode } \\
\text { Dia. } \\
\text { (in.) }\end{array}$ & $\begin{array}{l}\text { Orifice } \\
\text { Gas } \\
\text { Flow } \\
\text { (cfh) }\end{array}$ & $\begin{array}{l}\text { Shield } \\
\text { Gas } \\
\text { Flowb, c } \\
\text { (cfh) }\end{array}$ & $\begin{array}{l}\text { Pilot } \\
\text { Arc } \\
\text { Current } \\
\text { (A) }\end{array}$ & $\begin{array}{l}\text { Trans } \\
\text { Arc } \\
\text { Current } \\
\text { (A) }\end{array}$ \\
\hline \multicolumn{7}{|c|}{ Stainless Steel } \\
\hline 0.0625 & 0.030 & 0.040 & 1 & $20^{\mathrm{b}}$ & 3. & 25 \\
\hline 0.0938 & 0.052 & 0.0625 & 1.8 & $20^{\mathrm{b}}$ & 8 & 50 \\
\hline $0.1250^{\circ}$ & 0.052 & 0.0625 & 2.2 & $20^{b}$ & 8 & $75^{c}$ \\
\hline \multicolumn{7}{|c|}{ Carbon Steel } \\
\hline 0.0625 & 0.030 & 0.040 & 0.5 & $20^{\mathrm{c}}$ & 5 & 25 \\
\hline 0.0938 & 0.052 & 0.0625 & 1.5 & 20 & 8 & $70^{e}$ \\
\hline 0.1250 & 0.053 & 0.0625 & 20 & 20 & 8 & $80^{e}$ \\
\hline
\end{tabular}

a. Argon used as orifice gas.

b. $\mathrm{H}-1\left(1 \% \mathrm{H}_{2}, 99 \% \mathrm{Ar}\right)$ used as shielding gas on stainless steel.

c. Argon used as shielding gas on carbon steel.

d. Manual welding speed of $8 \mathrm{ipm}$.

e. These transferred arc currents should be used only with orifices recommended for keyhole welding. 


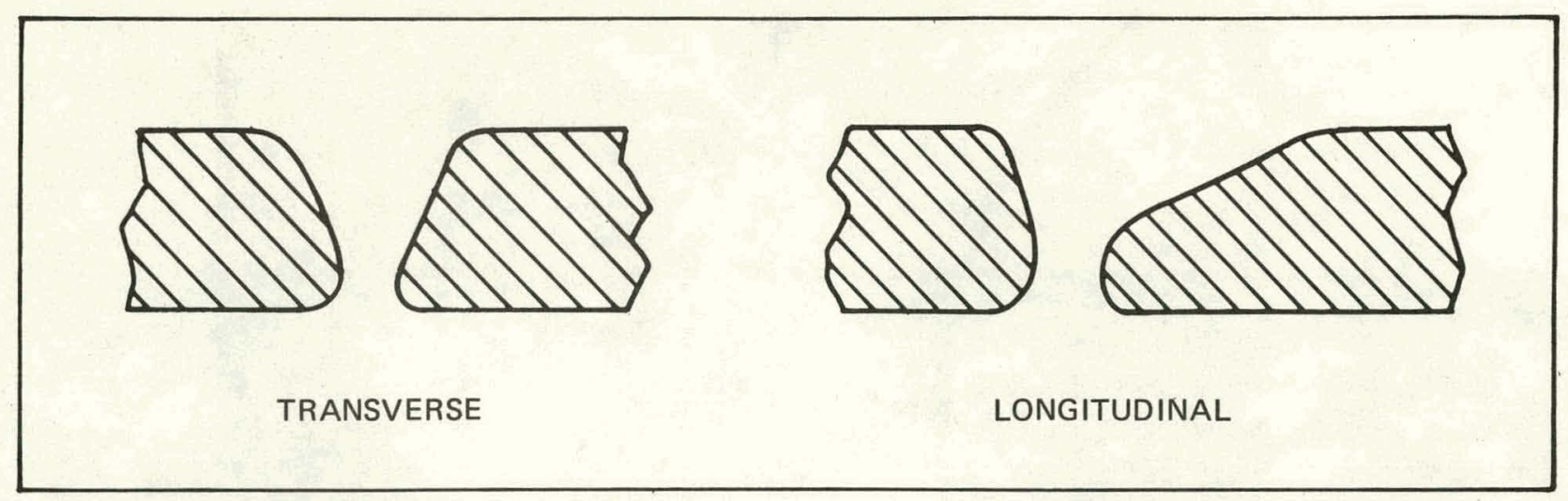

Figure 3. Sections of a Plasma Arc Welding Keyhole. The torch is moving to the left in the longitudinal section.

mode shows no advantage over GTA welding. For example, butt welds in 0.100 -inch-thick 304 stainless steel were made with $30-35$ amps (0.030-in. orifice) at $5 \mathrm{ipm}$. These welds were made with $100 \%$ argon shielding gas. For a comparable GTA weld, the required current would be approximately 100 amps.

\section{EXPERIMENTAL EVALUATIONS}

Point 1 in the introduction stated that plasma arc welding in the keyhole mode was less sensitive to aluminum in 21-6-9 stainless steel than was GTA welding. Referring back to that point, it was determined that with the same set of parameters, butt welds 0.100 -in. thick could be made in 304 stainless steel and in heats of 21-6-9 stainless steel containing from $<50$ to $180 \mathrm{ppm}$ of aluminum. For GTA welds made on this range of materials-with constant parameters-depth-to-width ratios of the fusion zones would vary by a factor of 2 . This fact was of great significance to the material problems being encountered at that time in GTA welding of 21-6-9 stainless steel. Since then, however, a technique using wire feed on the first pass has resolved the GTA welding difficulties; more significantly, nearly all use of 21-6-9 stainless steel has now been terminated.

According to Point 2 in the introduction, welds in narrow grooves could be made in the keyhole mode without spatter on the underside. The significance of Point 2 related primarily to replacement of electron beam (EB) full penetration welds. The need for minimum weld width precluded use of GTA welding, and EB welding typically resulted in spatter on the underbead side, which was deemed unacceptable. Numerous welds using various parameters and different grooves eventually delineated a satisfactory weld schedule. Figure 4 shows the underbeads of three welds made in 0.240-in.-thick stainless steel plate using $35 \mathrm{~A}$ (0.300-in. orifice), $10 \mathrm{ipm}, 5 \%$ hydrogen $95 \%$ argon shielding gas, and a weld groove that was 0.100 -in. wide at the bottom ( $4^{\circ}$ sidewall angle) and 0.200 -in. deep. The overbeads are seen in the flat-bottomed grooves in Figure 5, and an enlargement of one of the overbeads appears in Figure 6. Various aspects should be noted in Figures 5 and 6. The underbeads are smooth with good, positive drop-through. The overbeads are not smooth because of insufficient heat deposited at the bottom of the groove, and there is a slight melting of the upper edges of the grooves because of partial shunting of the arc current.

The weld current could not be increased without changing to the 0.052 -in. orifice. Such a change would increase the problem of shunting current to the groove edges, which would result in a net decrease in heat deposited at the groove bottom. This weld was judged acceptable, however, since the groove would be filled later by EB cold wire feed passes. Welds made on a mock-up of an actual unit were not as successful because of additional mass near the weld land, which made 


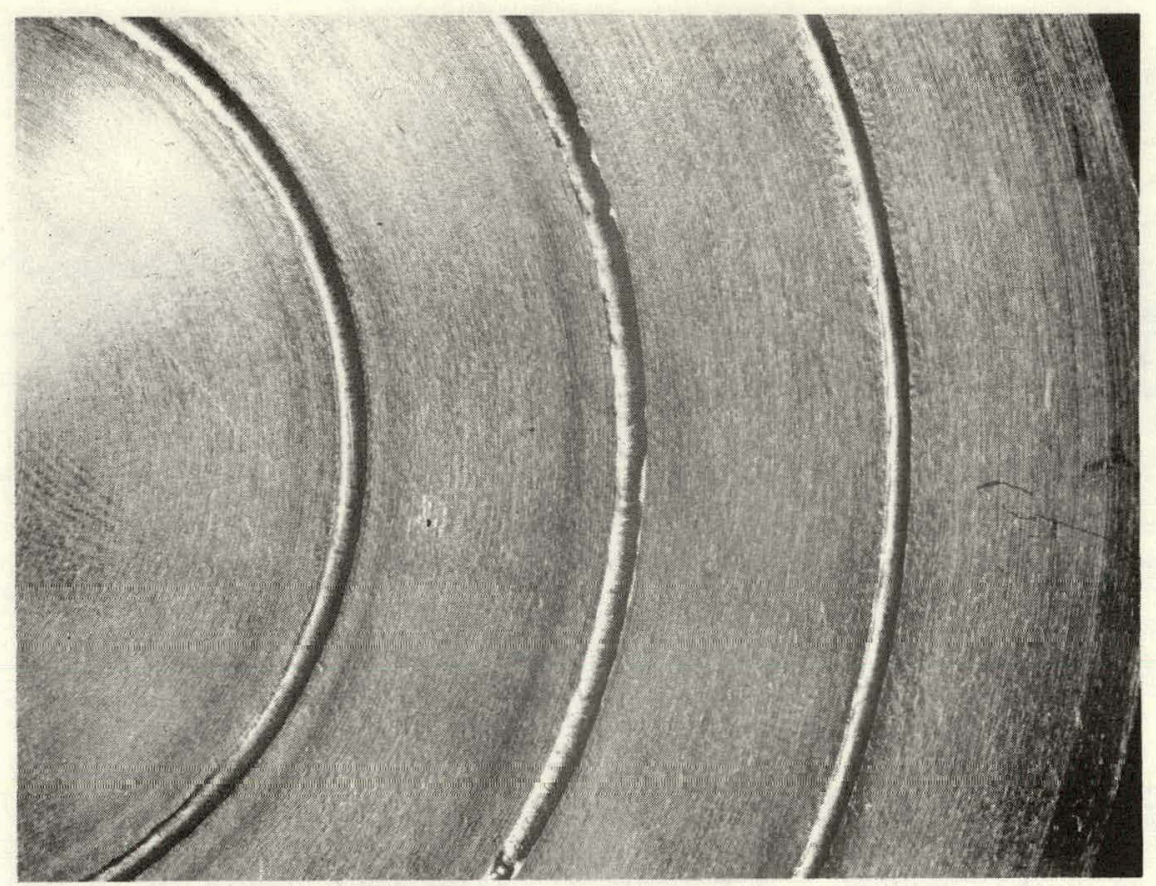

Figure 4. Underbeads of Keyhole Mode Welds in 0.240in. Plate. Actual spacing is $\mathbf{0 . 5}$ in. between welds.

Figure 5. Overbeads of Keyhole Mode Welds Shown at the Bottom of 0.200-in. Deep Grooves

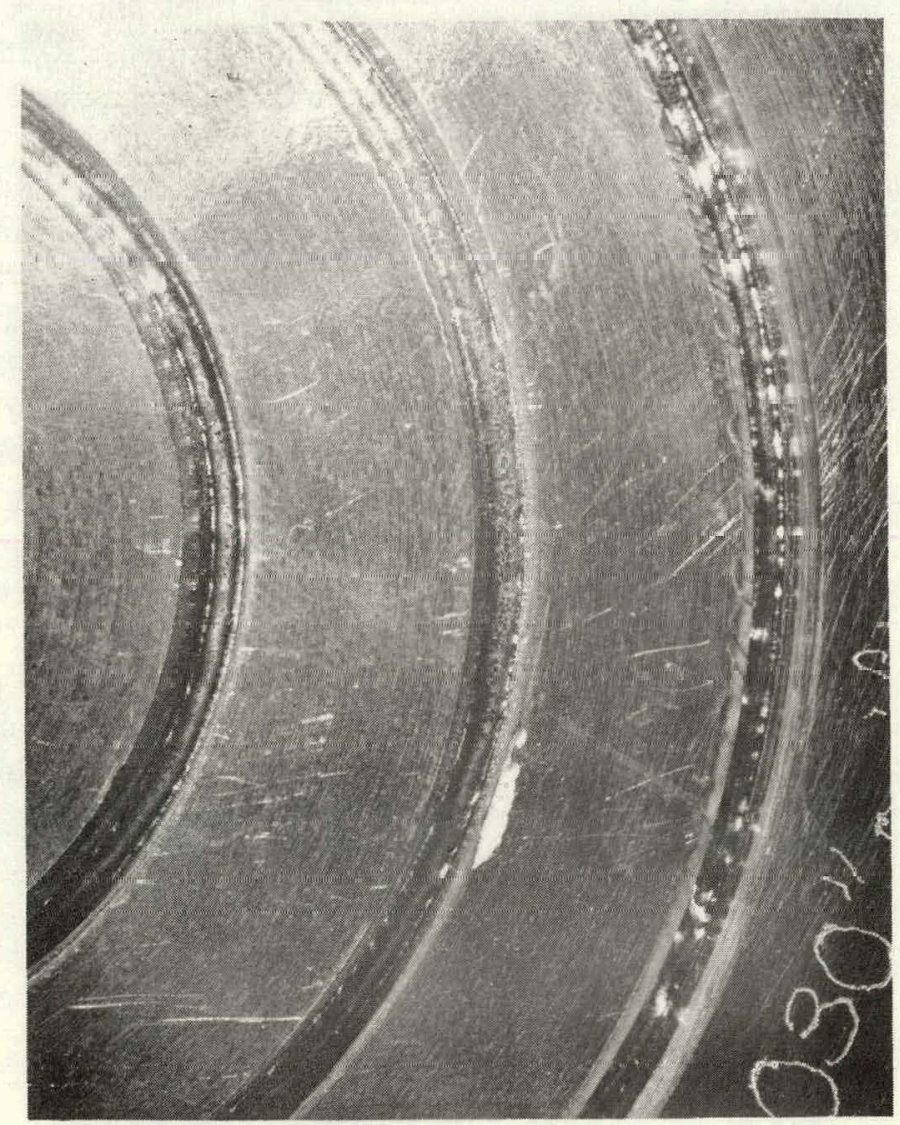




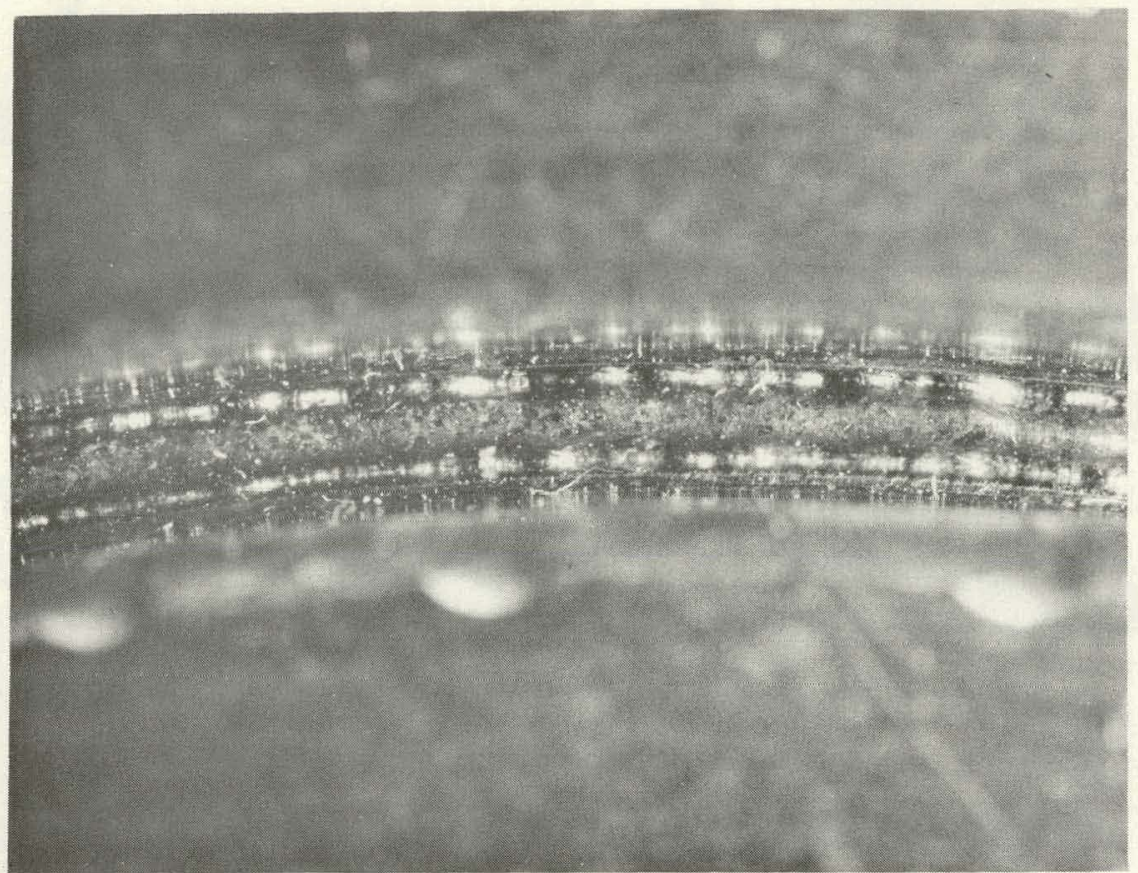

Figure 6. Enlargement of an Overbead Shown in Figure 5

the welds colder. To obtain a satisfactory fusion weld, a slight increase in weld heat could be obtained by increasing hydrogen content in the shielding gas to $10 \%$. Because of safety complications introduced by the use of $10 \% \mathrm{H}_{2}$ shielding gas and because of the unit redesign needed to accommodate the 0.250 -in. maximum weld-toorifice distance, this process was relegated to an alternate status for the specific program considered. However, for situations requiring a narrow weld and absolutely no spatter on the underbead side, plasma arc welding still holds promise.

The final area of potentially improved welding performance (Point 3 ) involved making full-section welds without the use of filler passes (butt welds rather than J-groove welds) in typical production units. A series of test welds showed that the maximum thickness of stainless steel that could be welded reliably was 0.200 inch. A current production unit (MC3262) was chosen as a test case since (1) the total thickness to be welded was within the established limit ( $\sim 0.150$ in.), (2) acceptable GTA welds had been developed with which to compare the plasma arc welds, and (3) either or both heat-sinks and chucks were available for holding and cooling the weld samples.

The primary difficulty encountered was in finding a slope-out schedule that would leave an overbead smooth enough to clean up when the weld reinforcement was turned to its final diameter. Figure 7 depicts two examples of unacceptable procedures: the first resulted from decreasing arc current without sufficient orifice gas flow reduction; the second was caused from insufficient current reduction as the orifice gas flow dropped. This destroyed the orifice. The latter case would be acceptable if the expense of an orifice insert for each weld was warranted; however, a similar destruction of the orifice during slope-in (required at the start of the weld to prevent spatter) makes keyholing impossible. Figure 8 shows typical overbeads resulting from a reduction of orifice gas flow to the minimum required for cooling with subsequent decrease in current. The depressions shown are deeper than the $0.040 \mathrm{in}$. removed from the radius during machining. 


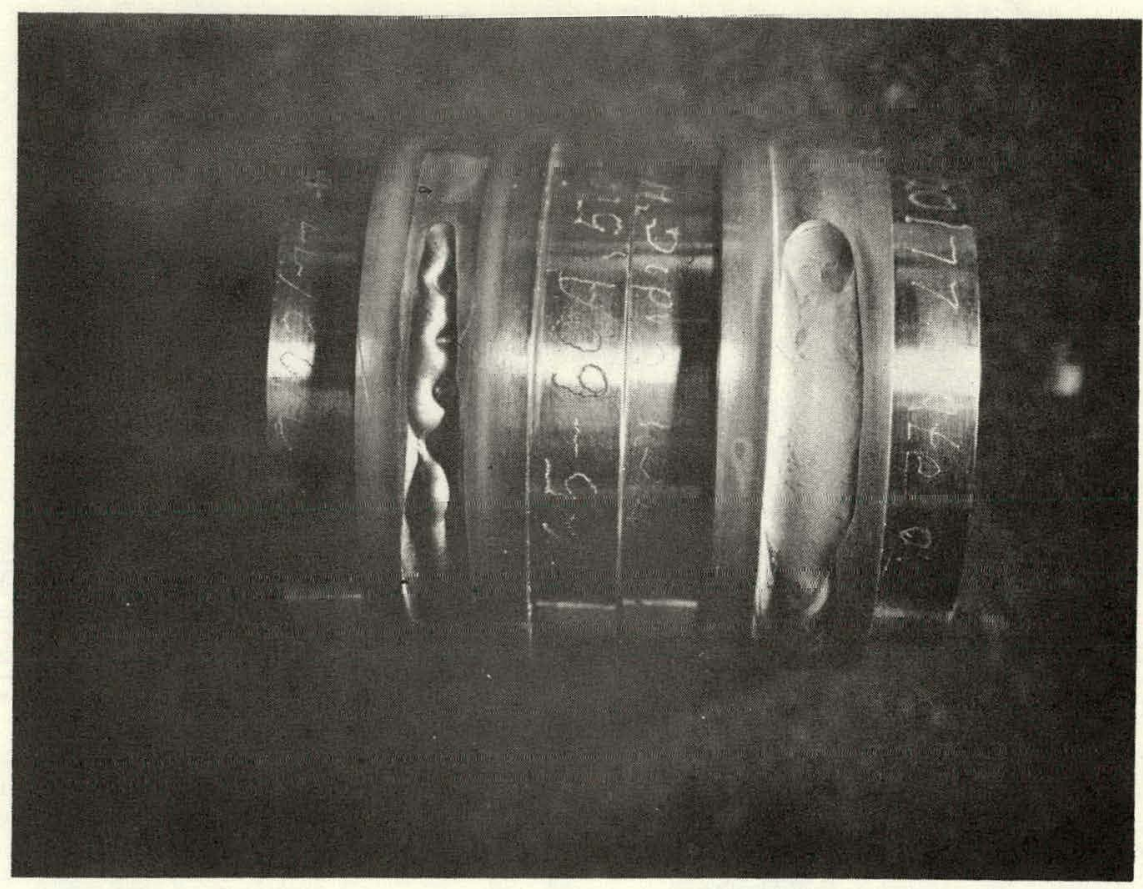

Figure 7. Keyhole Mode Weld Overbeads in Which Current was Decreased Without Sufficient Orifice Gas Flow Reduction (left) and Current Reduction was Insufficient for the Amount of Orifice Gas Flow Decrease (right)

Figure 8. Keyhole Mode Weld Overbeads in Which Orifice Gas Fluw was Reduced to the Minimum Required for Cooling, and the Current Subsequently Reduced

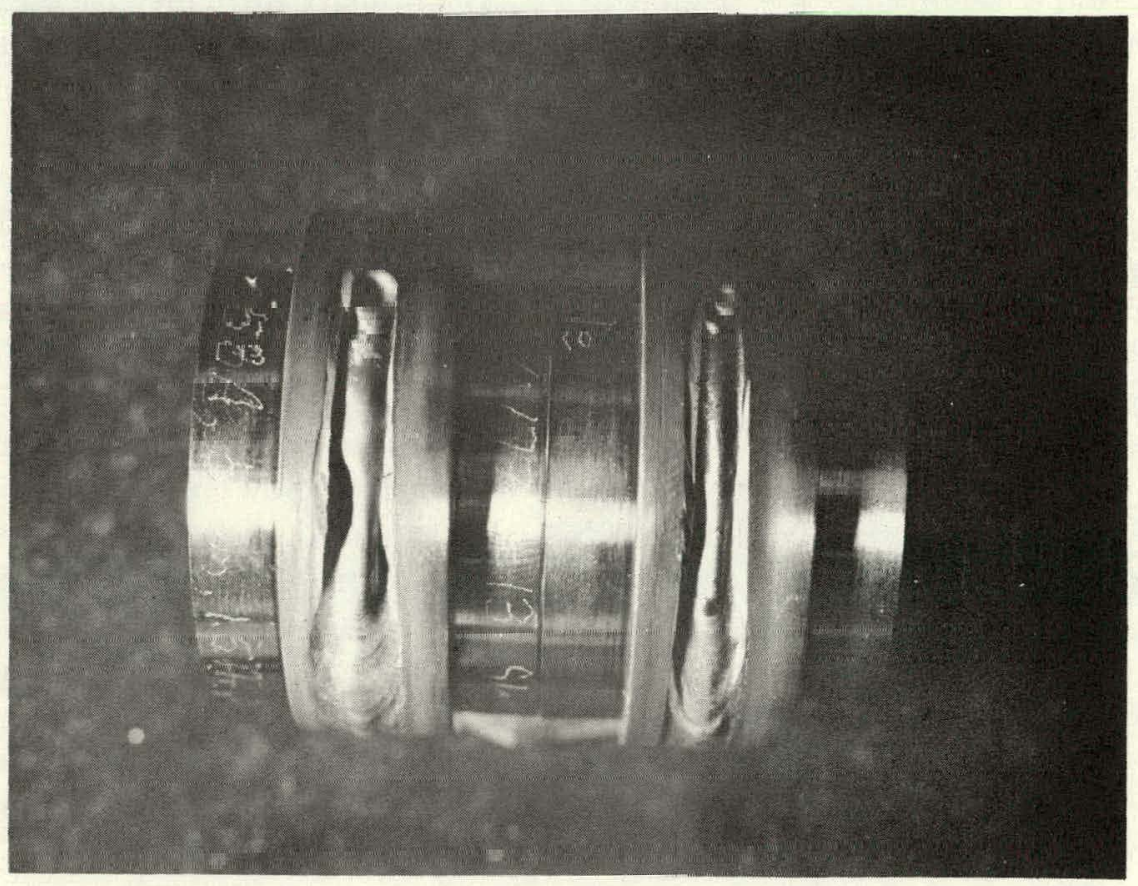




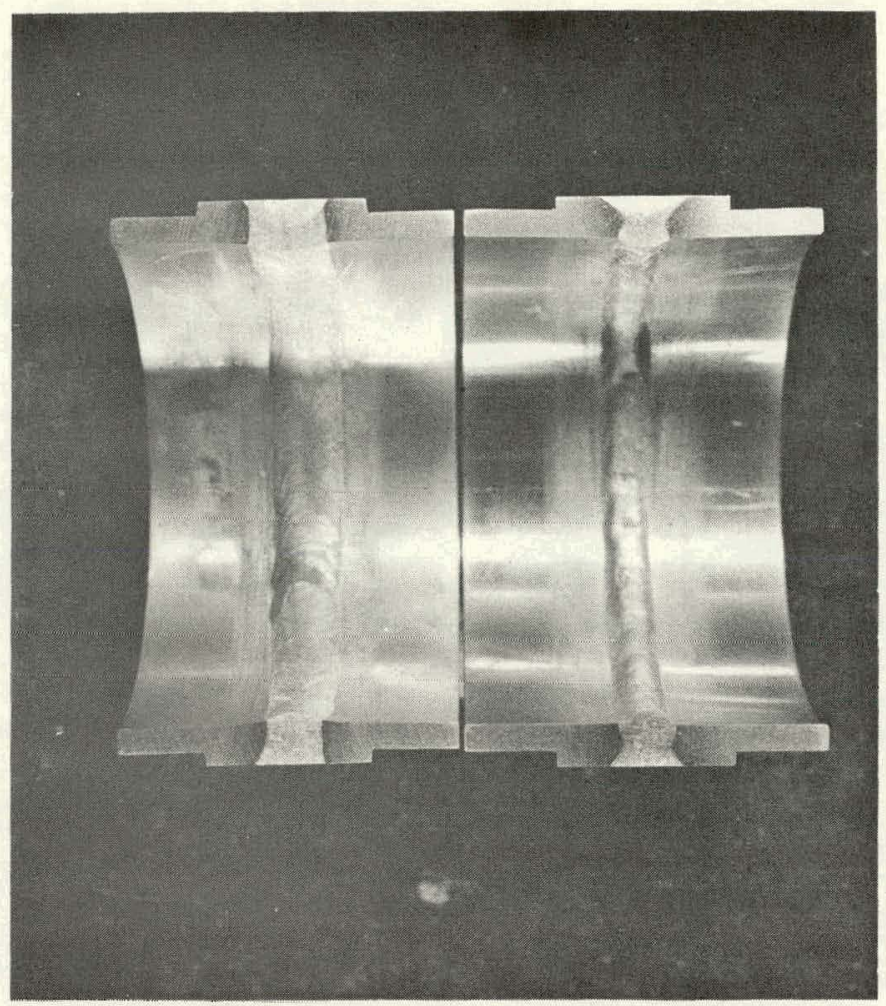

Figure 9. Comparison of Fusion Zones and Heat Affected Zones for an Acceptable GTA Weld (left) and the Best Plasma Arc Keyhole Mode Weld (right)

A more complicated slope-out procedure, in which orifice gas flow decreased further as the current dropped, did yield an acceptable overbead without destroying the orifice. Cross sections of this weld and of an accepted GTA weld are shown in Figure 9. The fusion zone of the plasma arc weld is definitely narrower over most of the weld, but the widths of the heat affected zones on either side of the fusion zone are greater. Therefore, in the case of the austenitic high-strength stainless steels that are of interest at Rocky Flats, the plasma arc weld is expected to be weaker than the GTA weld.

\section{CONCLUSIONS}

A detailed investigation was made regarding three areas of potential benefits from applying plasma arc welding (in the keyhole mode) to specific Rocky Flats welding needs. It was concluded that in none of the three areas did plasma arc welding prove a viable substitute for gas tungsten arc welding. In each case the benefits were either outweighed by the complications of implementing a new production process or there were no benefits. Looking beyond the present study and the needs it addressed, there is a general question concerning applicability of the keyhole mode of welding to circumferential welds. The matter of slope-in and slope-out must be addressed with significant effort since there is no known, commerically available equipment for accomplishing it except in the case of much heavier duty welders. Furthermore, a fairly sophisticated sequencing of parameters is required to obtain overbeads without significant depressions, and the determination of that sequence is a difficult matter. Considering these factors, circumferential plasma arc welds are practical only for cases in which the slope-out region can be left significantly depressed or in which a subsequent filler pass is used. The latter choice definitely limits the advantages of plasma arc welding over gas tungsten arc welding. 
RFP-2722 